University of Nebraska - Lincoln

DigitalCommons@University of Nebraska - Lincoln

\title{
Linking Microbial-Scale Findings to Farm-Scale Outcomes in a Dryland Cropping System
}

Cinthia K. Johnson

USDA-ARS

Brian J. Wienhold

University of Nebraska-Lincoln, Brian.Wienhold@ars.usda.gov

John W. Doran

USDA-ARS

Rhae A. Drijber

University of Nebraska-Lincoln, rdrijber1@unl.edu

Sara F. Wright

USDA-ARS

Follow this and additional works at: https://digitalcommons.unl.edu/usdaarsfacpub

Johnson, Cinthia K.; Wienhold, Brian J.; Doran, John W.; Drijber, Rhae A.; and Wright, Sara F., "Linking Microbial-Scale Findings to Farm-Scale Outcomes in a Dryland Cropping System" (2004). Publications from USDA-ARS / UNL Faculty. 1207.

https://digitalcommons.unl.edu/usdaarsfacpub/1207

This Article is brought to you for free and open access by the U.S. Department of Agriculture: Agricultural Research Service, Lincoln, Nebraska at DigitalCommons@University of Nebraska - Lincoln. It has been accepted for inclusion in Publications from USDA-ARS / UNL Faculty by an authorized administrator of DigitalCommons@University of Nebraska - Lincoln. 


\title{
Linking Microbial-Scale Findings to Farm-Scale Outcomes in a Dryland Cropping System*
}

\author{
CINTHIA K. JOHNSON, BRIAN J. WIENHOLD AND JOHN W. DORAN \\ USDA-ARS, $120 \mathrm{Keim} \mathrm{Hall,} \mathrm{Lincoln,} \mathrm{NE} 68583$ \\ RHAE A. DRIJBER \\ rdrijber1@unl.edu \\ Department of Agronomy and Horticulture, 279 Plant Science, University of Nebraska-Lincoln, \\ Lincoln, NE 68583
}

SARA F. WRIGHT

USDA-ARS, Building 001, BARC West, Rm 140, 10300 Baltimore Avenue, Beltsville, MD 20705

\begin{abstract}
Soil biological response to management is best evaluated in field-scale experiments within the context of the soil environment and crop; however, cost-effective methods are lacking to relate these data which span multiple spatial scales. We hypothesized that zones of apparent electrical conductivity $\left(\mathrm{EC}_{\mathrm{a}}\right)$ could be used to integrate soil properties (sampling-site scale), microbial-scale measures of vesicular-arbuscular mycorrhizal (VAM) fungi, and field-scale wheat yields from yield maps. An on-farm dryland experiment ( $250 \mathrm{ha})$ was established wherein two ( $-32-\mathrm{ha})$ fields were assigned to each phase of a winter wheat (Triticum aestivum L.) - corn (Zea mays L.) - proso millet (Panicum miliaceum L.) - fallow rotation. Each field was mapped and classified into four zones (ranges) of $\mathrm{EC}_{\mathrm{a}}$. Soil samples were collected from georeferenced sites within $\mathrm{EC}_{\mathrm{a}}$ zones and analyzed for multiple soil properties associated with productivity (07.5 and/or 0-30 cm). Additionally, VAM fungi were assessed using C16:1(cis)11 fatty acid methyl ester biomarker $\left(\mathrm{C} 16_{\mathrm{vam}}\right)$, glomalin immunoassay, and wet-aggregate stability (WAS) techniques (1-2 mm aggregates from 0 - to $7.5-\mathrm{cm}$ soil samples). Concentrations of $\mathrm{C}_{16} 6_{\text {vam }}$ and WAS increased among cropping treatments as: fallow $<$ wheat $<$ corn $<$ millet. Glomalin across crops and replicates, $\mathrm{C}_{16} 6_{\text {vam }}$ and WAS in fallow (crop effect removed), soil properties associated with productivity, and wheat yields were negatively correlated with $\mathrm{EC}_{\mathrm{a}}$ and different among $\mathrm{EC}_{\mathrm{a}}$ zones $(P \leq 0.05)$. Zones of $\mathrm{EC}_{\mathrm{a}}$ provide a point of reference for relating data collected at different scales. Monitoring cropping system parameters and profitability, over time, may allow linkage of microbial-scale processes to farm-scale economic and ecological outcomes.
\end{abstract}

Keywords: soil electrical conductivity, sustainable management, site-specific management, soil spatial heterogeniety, glomalin, hierarchy of experimental scale, biological indicators

\section{Introduction}

The identification of management strategies that promote the growth and activity of particular groups of soil microorganisms may be useful for treating specific agronomic problems, and for general improvement of the soil resource, crop yields, and economic return. Management practice engenders both direct (immediate) and indirect (temporal) effects on spatially variable interactions between microbes, the soil physical/chemical environment, and the crop (yield and residue inputs) (Doran and

*The U.S. Department of Agriculture, Agricultural Research Service, Northern Plains Area is an equal opportunity/affirmative action employer and all agency services are available without discrimination. 
Linn, 1994; Hendrix et al., 1990; Juma, 1993). Hence, soil biological function is best evaluated at the field scale within the context of the soil environment and the crop, an approach that spans multiple spatial scales. The ability to bridge the hierarchy of experimental scale, to link microbial processes to ecosystem outcomes and discern biotic and abiotic associations, is fundamental if we are to successfully manage soil microbial populations to address large-scale agronomic issues (Allen et al., 1992; O’Neill et al., 1991; Wright and Millner, 1994).

In dryland systems, no-till intensified rotational management increases yields (Anderson, 1998), soil C (Bowman et al., 1999), plant-available P (Bowman and Halvorson, 1997), and soil physical structure (Wright and Anderson, 2000). Although substantial investigation has been made of tillage and no-till impacts on soil biological function in wheat-fallow systems (Doran, 1980; Doran, 1987; Doran et al., 1998; Drijber et al., 2000; Kettler et al., 2000), little is known about the response of the soil microbial community to intensified rotational cropping under no-till. Furthermore, most of the above-mentioned research has been conducted in plot-scale experiments. In order to encompass soil heterogeneity, field-scale approaches are needed for realistic and comprehensive investigations of no-till intensified rotational management.

Geophysical sensors developed to measure soil electrical conductivity $\left(\mathrm{EC}_{\mathrm{a}}\right)$ are useful for assessing soil spatial heterogeneity. Measured $\mathrm{EC}_{\mathrm{a}}$ is a function of soil salinity, clay type/percentage, moisture, bulk density, and temperature (McNeill, 1980; Rhoades et al., 1989). However, in individual fields $\mathrm{EC}_{\mathrm{a}}$ is generally controlled by only one or two of these factors. Depending on soil characteristics, $\mathrm{EC}_{\mathrm{a}}$ can be used as a direct indicator of soil salinity (Lesch et al., 1992), moisture (Khakural and Robert, 1998), clay content (Williams and Hoey, 1987) and/or nitrate (Eigenberg et al., 2002). When the soil properties contributing to measured $\mathrm{EC}_{\mathrm{a}}$ are also yield limiting, $\mathrm{EC}_{\mathrm{a}}$ maps provide an excellent framework for soil sampling schemes that reflect spatial variability in production potential (Corwin et al., 2003; Johnson et al., 2001).

A 250-ha on-farm experiment, the Farm-Scale Intensive Cropping Study (FICS), was initiated to evaluate the utility of new technologies, including $\mathrm{EC}_{\mathrm{a}}$ sensors, yield monitors, global positioning systems, and geographic information systems, for the field-scale assessment of management. The research described in this manuscript provides foundational information for this long-term goal. In 1999, the site was converted to a no-till winter wheat (Triticum aestivum L.) - corn (Zea mays L.) proso millet (Panicum miliaceum L.) - fallow rotation after nearly 70 years of traditional wheat-fallow management using conventional tillage. In foundational experiments, the FICS was $\mathrm{EC}_{\mathrm{a}}$ mapped and classified into four management zones based on ranges of $\mathrm{EC}_{\mathrm{a}}$. A geo-referenced stratified soil sampling scheme was created from this classified $\mathrm{EC}_{\mathrm{a}}$ map. Statistical comparison of sampled soils revealed that zones of $\mathrm{EC}_{\mathrm{a}}$ effectively described within-field variability in soil physical, chemical, and biological properties indicative of yield potential at $0-7.5$ and/or $0-30 \mathrm{~cm}$ depths of measurement $(P \leq 0.06)$ (Johnson et al., 2001).

The effectiveness of $\mathrm{EC}_{\mathrm{a}}$ mapping for integrating multiple soil properties suggests interesting potential applications for this technology. Classification based on ranges of $\mathrm{EC}_{\mathrm{a}}$ may provide the necessary framework for relating spatial and temporal data collected at different levels of scale (Figure 1). We hypothesized that $\mathrm{EC}_{\mathrm{a}}$ zones could be used to delineate within-field variability in the presence and activity of specific 


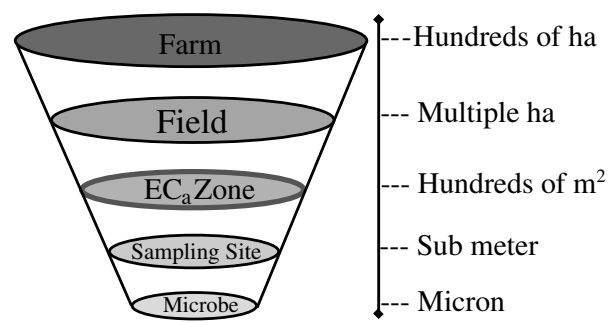

Figure 1. The use of $\mathrm{EC}_{\mathrm{a}}$ classification as a pivotal point through which measurements spanning the hierarchy of experimental scale can be related.

groups of microorganisms (microbial scale) that can subsequently be related to corresponding variations in the soil environment (sampling-site scale [hundreds of $\mathrm{m}^{2}$ ]) and crop productivity (field scale [multiple ha]). If these relationships can be established, $\mathrm{EC}_{\mathrm{a}}$-classified zones may serve as an intermediate point of reference through which data collected at much larger or smaller levels of scale can be integrated.

The vesicular-arbuscular mycorrhizal (VAM) fungi were selected for microbialscale evaluations in this study because of their contributions to both the crop and the soil. These organisms promote crop growth directly by conferring drought resistance (Ellis et al., 1985), expanding nutrient uptake and availability, and suppressing disease (Sylvia et al., 1998). The VAM fungi also benefit soil aggregation. In 1996, Wright and Upadhyaya identified a glycoprotein, called glomalin, which is produced by VAM hyphae. Glomalin acts as a "glue" (Wright and Anderson, 2000) that, coupled with mechanical hyphal entanglement (Miller and Jastrow, 1992), binds soil particles together.

We evaluated populations of VAM using fatty acid methyl ester (FAME) extraction and analysis for the C16:1(cis)11 biomarker $\left(\mathrm{C} 16_{\text {vam }}\right)$ (Olsson et al., 1995). Direct and indirect estimates of VAM contributions to soil aggregation were made using glomalin immunoassay (Wright and Upadhyaya, 1996) and soil wet-aggregate stability (WAS) (Tisdall and Oades, 1982) techniques, respectively. In addition to these microbial-scale measures of VAM presence and activity, sampling-site scale assessment of soil condition (soil physical, chemical and biological properties) and field-scale maps of winter wheat yields were made using a yield monitor.

The primary objective of this study was to evaluate the feasibility of using $\mathrm{EC}_{\mathrm{a}}$ classified within-field variability to relate observations made at different levels of experimental scale. A secondary objective was to establish baseline measures of VAM fungi during the first year of newly imposed no-till winter wheat - corn - proso millet-fallow rotational management. In the future, these baseline data can be compared with repeated measurements, taken over time, as a means to monitor soil ecological response to no-till intensified rotational management.

\section{Materials and methods}

Experimental data were collected from the FICS, a newly established on-farm experiment located $30 \mathrm{~km}$ east of Sterling, $\mathrm{CO}$ in the semiarid Central Great Plains. 
The site is a contiguous section of farmland ( $250 \mathrm{ha}$ ) that was converted from conventionally tilled winter wheat - fallow to an intensified no-till winter wheat - corn proso millet - fallow rotation in 1999. Cropping treatments were applied to eight fields within the FICS such that each phase of the four-year rotation is present in two replicates each year. Soils are a mixture of Platner (fine, smectitic, mesic Aridic Paleustolls), Weld (fine, smectitic, mesic Aridic Argiustolls), and Rago (fine, smectitic, mesic Pachic Argiustolls) loams. Highly variable precipitation occurs mainly in May and June, averaging $420 \mathrm{~mm}$ annually. Mean annual temperature is $10^{\circ} \mathrm{C}$.

\section{$E C_{a}$ classification and soil sampling}

The FICS site was EC $_{\mathrm{a}}$ mapped in March 1999 using a Veris 3100 Sensor Cart (Veris Technologies, a division of Geoprobe Systems, Salina, Kansas) ${ }^{1}$ and Trimble AG132 D global positioning system (Trimble Navigation Ltd., Sunnyvale, CA $)^{1}$. Each of the eight fields comprising the FICS site was individually classified into four zones (ranges) of $\mathrm{EC}_{\mathrm{a}}$ : low, medium low, medium high, and high. To do this, $\mathrm{EC}_{\mathrm{a}}$ maps from each field were interpolated by inverse-distance weighting and partitioned into 12 classes (10-m grid cell resolution) using unsupervised classification (ERDAS Inc., 1997) ${ }^{1}$, an iterative process that groups clusters of statistically similar data (Figure 2a). The 12 classes were then recoded into four (Figure $2 \mathrm{~b}$ ) by subjectively adjusting the four $\mathrm{EC}_{\mathrm{a}}$ class ranges until they reflected the dominant visible spatial patterns in the gray-scale interpolated $\mathrm{EC}_{\mathrm{a}}$ map (Figure 2a). This method groups spatially related $\mathrm{EC}_{\mathrm{a}}$ data points into naturally occurring clusters.

Ninety six geo-referenced soil-sampling sites were identified across the FICS, twelve within each of the eight fields, three per $\mathrm{EC}_{\mathrm{a}}$ zone. Sites were placed in the center of distinct, non-adjoining sections within each $\mathrm{EC}_{\mathrm{a}}$ zone to avoid transition areas, and selected to provide comprehensive coverage of each field (Figure 2b). Wheat and fallow fields were sampled in mid-July 1999 following wheat harvest, while corn and millet fields were sampled in mid-November 1999 after corn harvest. At each of the sites, seven soil cores were taken, within a $75-\mathrm{cm}^{2}$ area, at $0-7.5$ and $7.5-30 \mathrm{~cm}$ depths. Each sample was composited, transported to the laboratory in a cooler, and stored at $5^{\circ} \mathrm{C}$ prior to air-drying and passage through a two-mm sieve. Analyses from 0-7.5 and 7.5-30 cm depth samples were combined and weighted to calculate $0-30 \mathrm{~cm}$ depth measurements. A subsample of the 0-7.5 depth samples was dry-sieved to segregate $1-2 \mathrm{~mm}$ size soil aggregates. This soil fraction was used to

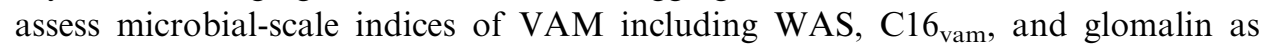
described below.

\section{Whole soil analyses (sampling-site scale)}

All whole-soil analyses were made for both sampling depths $(0-7.5$ and 7.5-30 cm). Bulk density was determined using the mass of soil (dry mass basis) and the volume of the seven cores taken from each sampling site. A subsample of soil was used to 
(a)

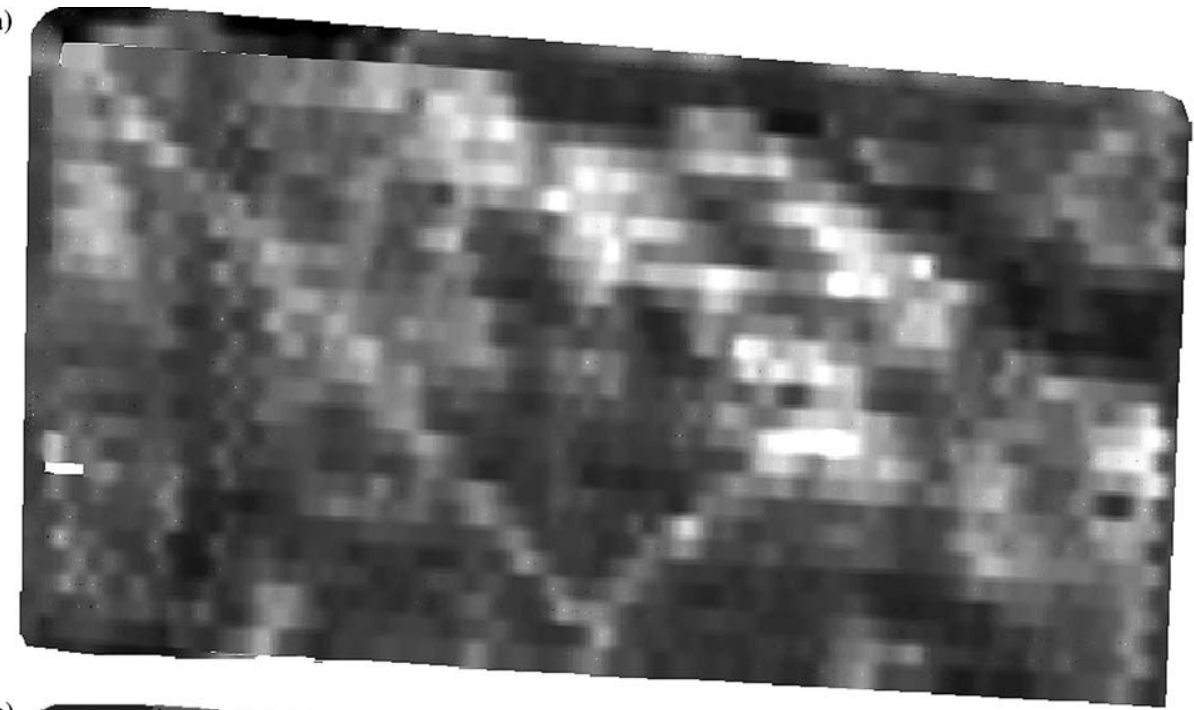

(b)
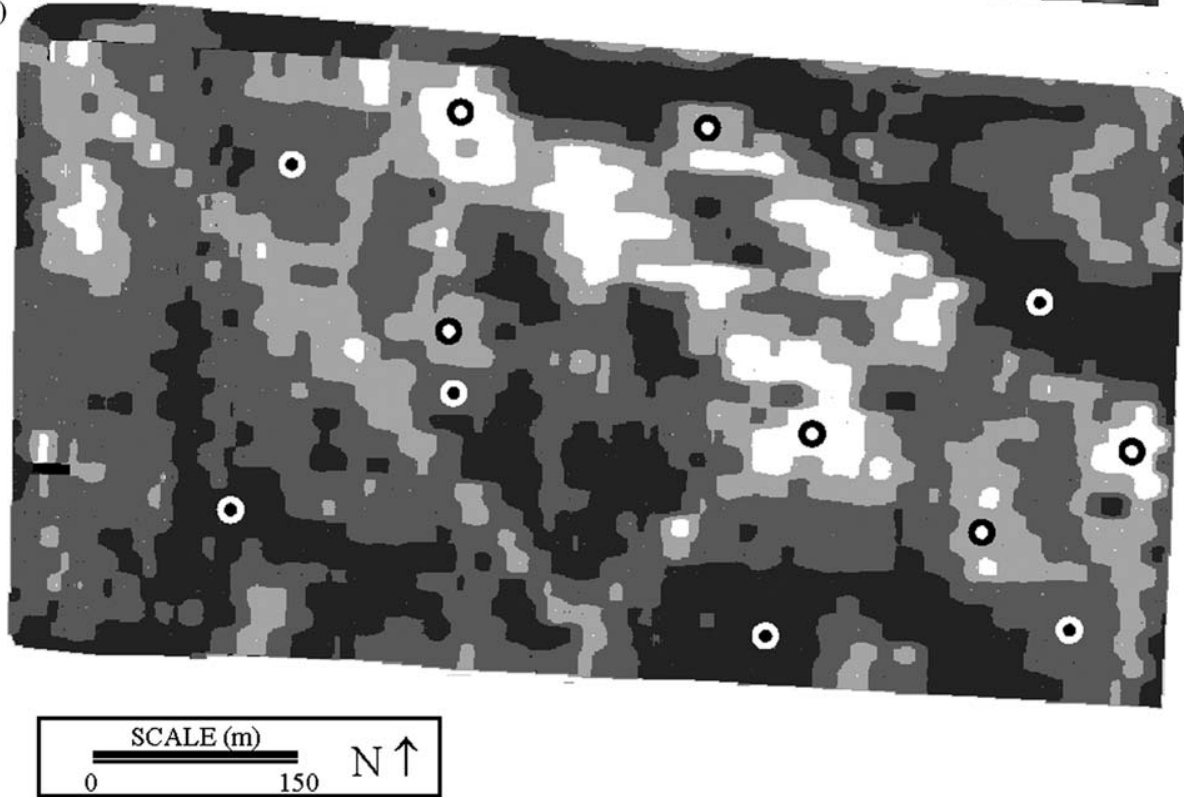

Figure 2. A gray-scale electrical conductivity map for the field in the northwest corner of the experimental site (a) and the same map following recoding into four electrical-conductivity zones (b). Variations in color, from dark to light, correspond to increasing conductivity, and "O" symbols represent selected soil sampling sites.

measure gravimetric water content. The remainder was air dried and analyzed for total $\mathrm{C}$ and $\mathrm{N}$ using a Carlo Erba NA 100 (CE Elantech, Lakewood, NJ) ${ }^{1}$, whole soil and particulate organic matter $(0.05-2 \mathrm{~mm})$ by loss on ignition (Cambardella et al., 2001), extractable P by the Bray-1 method (Bray and Kurtz, 1945), percent clay 
(Kettler et al., 2001), and pH (1:1 soil:water mixture). Assessment of microbial biomass $\mathrm{C}$ and $\mathrm{N}$ was also made on whole-soil samples using microwave irradiation (Islam et al., 1998).

\section{Soil aggregate (1-2 mm) analyses (microbial-scale)}

Measures of VAM presence and activity were made using 1-2 mm size soil aggregates (0-7.5 sampling depth only), a fraction significant to soil physical structure. Depending on the site sampled, the 1-2 mm size fraction represented $12.3-42.6 \%$ of whole soil, falling around $20 \%$ for most samples. Stability of the $1-2 \mathrm{~mm}$ soil aggregates was determined using the wet sieving procedure and apparatus described by Kemper and Rosenau (1986). Four grams of separated aggregates (corrected for the weight of coarse material $>0.25 \mathrm{~mm}$ ) were placed on a $0.25-\mathrm{mm}$ sieve, capillary wetted with deionized water, and wet sieved for $5 \mathrm{~min}$ in deionized water at 38 cycles $\min ^{-1}$. Following air drying of the soil remaining on the sieve, WAS was reported as a percentage of initial soil weight.

Total ester-linked FAMEs were extracted from the 1-2 mm aggregate fraction subsamples by mild alkaline hydrolysis, a process that does not methylate-free fatty acids (Grogan and Cronan, 1997; Kates, 1986). The 1-2 mm soil aggregate fraction was hydrolyzed using freshly prepared $0.2 \mathrm{M}$ potassium hydroxide in methanol, and the resulting FAMEs were partitioned into hexane (White et al., 1979). Following saponification to release ester-linked FAMEs, methyl-nonadecanoate $(0.05 \mu \mathrm{g} / \mu \mathrm{l})$ was added to the extract as an internal standard. Released FAMEs were separated by capillary gas chromatography, using helium as a carrier gas, on a Hewlett Packard 5890 Series II gas chromatograph. This instrument contained an Ultra $2 \mathrm{HP}$ (50 m, $0.2 \mathrm{~mm}$ I.D., $0.33 \mu \mathrm{m}$ film thickness) and was run in split mode (44:1) with a 0.75 min purge time. Helium was the carrier gas. Injector and flame ionization detectors were maintained at 280 and $300^{\circ} \mathrm{C}$, respectively, and oven temperature was ramped from 50 to $160^{\circ} \mathrm{C}$ at $40^{\circ} \mathrm{C} \mathrm{min}{ }^{-1}$ and held for $2 \mathrm{~min}$, then ramped at $3^{\circ} \mathrm{C} \mathrm{min}^{-1}$ to $300^{\circ} \mathrm{C}$ and held for $30 \mathrm{~min}$. The $\mathrm{C} 16_{\text {vam }}$ was identified by retention-time and confirmed by gas chromatography mass spectrometry. Concentrations of $\mathrm{C}_{16} 6_{\text {vam }}$ were calculated from peak areas and reported as nmol $\mathrm{g}^{-1}$ soil.

Duplicate analyses were made on soil aggregates for total and easily extractable glomalin (EE glomalin), and for immunoreactive total (IRT) and immunoreactive EE glomalin (IREE glomalin). Extractions were carried out as per Wright and Upadhyaya (1996). The easily extractable fraction was removed by autoclaving soil with $20-\mathrm{mM}$ citrate, $\mathrm{pH} 7$, for $30 \mathrm{~min}$ at $121^{\circ} \mathrm{C}$. The total glomalin fraction was removed by autoclaving soil with $50-\mathrm{mM}$ citrate, $\mathrm{pH} 8$, for $60 \mathrm{~min}$ at $121^{\circ} \mathrm{C}$. This was done three times for each soil sample; the resulting extracts were combined, stored at $4{ }^{\circ} \mathrm{C}$ and analyzed within 2 weeks. Extracts of total and EE glomalin were assayed for total protein, using the Bradford protein assay, and for immunoreactive protein, using enzyme-linked immunosorbent assay with monoclonal antibody 31B11 (Wright and Upadhyaya, 1996; Wright and Upadhyaya, 1998). 


\section{Wheat yield analyses (field-scale)}

Yield measurements were taken for wheat crops in 1999 and 2000 using a MicroTrak grain yield monitor (Micro-Trak Systems Inc., Eagle Lake, MN) ${ }^{1}$ and a Trimble AG132 D global positioning system (Trimble Navigation Ltd., Sunnyvale, CA $)^{1}$. Using Farm HMS software (Red Hen Systems, Ft. Collins, CO) ${ }^{1}$, data were edited and calibrated with whole-field yield averages from grain weigh-ticket information.

\section{Statistical analyses}

The significance of classification by $\mathrm{EC}_{\mathrm{a}}$ ranges was determined for each of the physical, chemical, and biological attributes of whole-soil, VAM indices in the 1-2 $\mathrm{mm}$ soil aggregates, and crop yields. This was done using an ANOVA for a randomized complete block strip-split plot design in two replicates with crop (wheat, corn, millet or fallow) and $\mathrm{EC}_{\mathrm{a}}$ zone (low, medium-low, medium-high, and high) as treatment factors. For microbial analyses, ANOVA was also applied to fallow treatments alone ( $3 \mathrm{df}$ for error) to eliminate crop* $\mathrm{EC}_{\mathrm{a}}$ interactions potentially masking $\mathrm{EC}_{\mathrm{a}}$ zone significance. Measures of $\mathrm{VAM}$ not different among $\mathrm{EC}_{\mathrm{a}}$ zones within fallow treatments and showing non-significant replicate* $\mathrm{EC}_{\mathrm{a}}$-zone interactions $(\alpha=0.2)$ were put through a second ANOVA using pooled data (replicate*EC $\mathrm{C}_{\mathrm{a}}$ zone removed). This approach increased df for error from 3 to 19 to test whether non-significance was due to insufficient df. All statistical analyses for glomalin concentrations were conducted on the mean of duplicate measures.

To eliminate the confounding effect of crop, Pearson correlation coefficients were estimated for pairs of whole soil and 1-2 mm size fraction variables in the fallow fields only, as were regression analyses relating C16 vam and IRT glomalin $(n=24)$. All statistical analyses were performed using SAS (SAS Institute, 1997) ${ }^{1}$ and differences were declared significant at the 0.05 level, unless stated otherwise.

\section{Results and discussion}

\section{Whole-soil analyses (sampling-site scale)}

In this semiarid cropping system, soil properties related to yield potential (moisture content, total and particulate organic matter, total $\mathrm{C}$ and $\mathrm{N}$, extractable $\mathrm{P}$, and microbial biomass $\mathrm{C}$ and $\mathrm{N})$ were different among $\mathrm{EC}_{\mathrm{a}}$ zones $(P \leq 0.05)$ and negatively correlated with $\mathrm{EC}_{\mathrm{a}}$ at one or both soil depths. Conversely, properties associated with erosion (bulk density, clay percentage, and $\mathrm{pH}$ ) were different among $\mathrm{EC}_{\mathrm{a}}$ zones $(P=0.06)$ but positively correlated with $\mathrm{EC}_{\mathrm{a}}$ at one or both soil depths. Data on surface $(0-7.5 \mathrm{~mm})$ whole-soil measurements is provided in Table 1. Additional information on the relationships between $\mathrm{EC}_{\mathrm{a}}$ and soil physical, chemical, and biological properties (at both depths of measurement) is given by Johnson et al. (2001). 


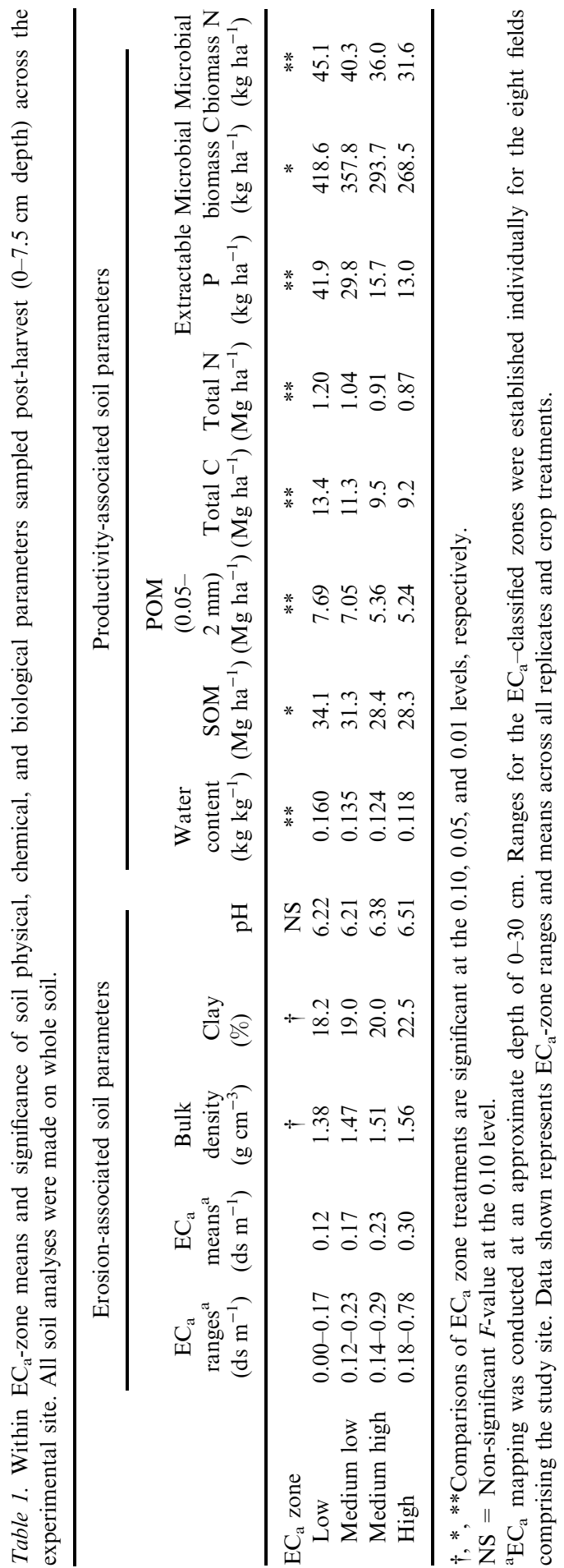




\section{Aggregate (1-2 mm) analyses (microbial-scale)}

Neither WAS nor $\mathrm{C}_{16}$ vam was different among $\mathrm{EC}_{\mathrm{a}}$ zones when evaluated across replicates and crop treatments (Table 2). However, when evaluated within fallow fields only, WAS was highly related $(P \leq 0.05)$ and $\mathrm{C} 16_{\text {vam }}$ showed trends $(P \leq 0.13)$ toward a relationship with $\mathrm{EC}_{\mathrm{a}}$ zones. A second ANOVA using pooled data (replicate* $\mathrm{EC}_{\mathrm{a}}$ zone removed) revealed that $\mathrm{C}_{16} 6_{\text {vam }}$ was also significantly different among $\mathrm{EC}_{\mathrm{a}}$ zones $(P \leq 0.006)$ (Table 2). Both WAS and $\mathrm{C} 16_{\text {vam }}$ were negatively correlated with $\mathrm{EC}_{\mathrm{a}}$.

Whole soil FAME analysis can discern cropping patterns (Cavigelli et al., 1995) and distinguish natural grasslands from managed systems (Drijber et al., 2000). Moreover, Drijber et al. (2000) found that the principal discriminating factor for the

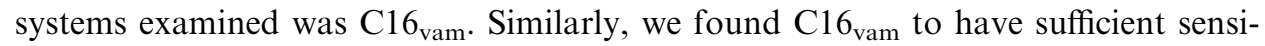
tivity to separate cropping treatments, with highest concentrations in millet fields, followed by corn, wheat, and fallow (Table 2). Because VAM fungi are obligate symbionts (require a plant host), it is reasonable that $\mathrm{C} 16_{\text {vam }}$ concentrations were lowest in fallow treatments. However, the order of non-fallow crop-treatment separation by $\mathrm{C}_{16} 6_{\text {vam }}$ presents interesting questions. Do higher concentrations of $\mathrm{C}_{16} 6_{\text {vam }}$ in millet and corn treatments indicate that these crops are more mycorrhizal

Table 2. Within-EC $\mathrm{E}_{\mathrm{a}}$ zone (across replicate and crop treatments) and within-crop treatment means and significance for measures of vesicular arbuscular mycorrhizal presence and activity. All analyses were made on the 1-2 mm aggregate-size fraction of soil (0-7.5 cm depth)

\begin{tabular}{|c|c|c|c|c|c|c|}
\hline & $\begin{array}{c}\text { Wet } \\
\text { aggregate } \\
\text { stability } \\
(\%)\end{array}$ & $\begin{array}{c}\text { C16:cis } \\
11 \text { fatty acid } \\
\left(\mathrm{nmol} \mathrm{g}^{-1} \text { soil }\right)\end{array}$ & $\begin{array}{c}\text { Total } \\
\text { glomalin } \\
\left(\mathrm{mg} \mathrm{g}^{-1} \text { soil }\right)\end{array}$ & $\begin{array}{l}\text { Immunoreac- } \\
\text { tive total } \\
\text { glomalin } \\
\left(\mathrm{mg} \mathrm{g}^{-1} \text { soil }\right)\end{array}$ & $\begin{array}{l}\text { Total easily } \\
\text { extractable } \\
\text { glomalin } \\
\left(\mathrm{mg} \mathrm{g}^{-1} \text { soil }\right)\end{array}$ & $\begin{array}{c}\text { Immunoreactive } \\
\text { easilyextractable } \\
\text { glomalin } \\
\left(\mathrm{mg} \mathrm{g}^{-1} \text { soil }\right)\end{array}$ \\
\hline $\mathrm{EC}_{\mathrm{a}}$ Zone & NS $(\dagger)^{\mathrm{a}}$ & $\mathrm{NS}(* *)^{\mathrm{b}}$ & $* *$ & $* *$ & $\dagger$ & $* *$ \\
\hline Low & $\ddagger 21.8 \mathrm{a}(21.5 \mathrm{a})$ & $5.45 \mathrm{a}(4.11 \mathrm{a})$ & $2.64 \mathrm{a}$ & $0.50 \mathrm{a}$ & $0.46 \mathrm{a}$ & $0.29 \mathrm{a}$ \\
\hline Med. Low & $20.2 \mathrm{a}(17.9 \mathrm{ab})$ & $5.52 \mathrm{a}(3.15 \mathrm{~b})$ & $2.18 b$ & $0.38 \mathrm{~b}$ & $0.44 \mathrm{ab}$ & $0.24 b$ \\
\hline Med. High & $20.5 a(17.5 a b)$ & $5.80 \mathrm{a}(2.69 \mathrm{~b})$ & $1.75 \mathrm{c}$ & $0.30 \mathrm{bc}$ & $0.42 b$ & $0.19 \mathrm{c}$ \\
\hline High & $19.9 \mathrm{a}(17.0 \mathrm{~b})$ & $5.69 \mathrm{a}(2.86 \mathrm{~b})$ & $1.69 \mathrm{c}$ & $0.27 \mathrm{c}$ & $0.39 \mathrm{c}$ & $0.16 \mathrm{c}$ \\
\hline $\mathrm{SE}_{\mathrm{d}} \S$ & $1.054(1.76)$ & $0.645(0.292)$ & 0.070 & 0.029 & 0.010 & 0.014 \\
\hline Crop & $\dagger$ & $* *$ & NS & NS & NS & NS \\
\hline Millet & $25.6 \mathrm{a}$ & $9.24 \mathrm{a}$ & $2.07 \mathrm{ab}$ & $0.39 \mathrm{a}$ & $0.42 \mathrm{a}$ & $0.23 b$ \\
\hline Corn & $20.9 b$ & $5.46 \mathrm{~b}$ & $2.23 \mathrm{a}$ & $0.39 \mathrm{a}$ & $0.44 \mathrm{a}$ & $0.27 \mathrm{a}$ \\
\hline Wheat & $18.5 \mathrm{bc}$ & $4.44 b c$ & $1.95 \mathrm{~b}$ & $0.37 \mathrm{ab}$ & $0.42 \mathrm{a}$ & $0.18 \mathrm{c}$ \\
\hline Fallow & $17.6 \mathrm{c}$ & $3.22 \mathrm{c}$ & $2.01 \mathrm{~b}$ & $0.30 \mathrm{~b}$ & $0.43 \mathrm{a}$ & $0.21 b$ \\
\hline $\mathrm{SE}_{\mathrm{d}} \S$ & 1.048 & 0.447 & 0.063 & 0.029 & 0.009 & 0.011 \\
\hline
\end{tabular}

$\dagger$, **Comparisons of crop or $\mathrm{EC}_{\mathrm{a}}$-zone treatments are significant at the 0.10 and 0.01 levels, respectively. NS Non-significant $F$-value at the 0.1 level.

tValues followed by the same letter within each $\mathrm{EC}_{\mathrm{a}}$-zone or crop column are not significantly different (0.10).

$\S$ Standard error of the difference between sample means.

${ }^{\mathrm{a}}$ Information in ( ) within an $\mathrm{EC}_{\mathrm{a}}$-zone column is from ANOVA of fallow treatments only.

${ }^{\mathrm{b}}$ Information in ( ) within an $\mathrm{EC}_{\mathrm{a}}$-zone column is from ANOVA of fallow treatments only using pooled data. 
than wheat, or are these concentrations a reflection of VAM response to weatherinduced conditions in the soil environment or time of sampling?

Both plant species and soil edaphic factors select for VAM populations (Johnson et al., 1992). Because soil samples were taken from the FICS during the first year following conversion to a winter wheat-corn-proso millet-fallow rotation, and historical management was monoculture wheat-fallow, it is possible that indigenous VAM populations had greater affinity for millet and corn than for wheat. Furthermore, wheat fields often have low mycorrhizal propagule densities and wheat plants can remain non-mycorrhizal for most of the growing season (Hetrick and Bloom, 1983; Yocom et al., 1985). These findings support plant species as the dominant factor determining $\mathrm{C}_{16} 6_{\text {vam }}$ concentrations in the FICS.

Conflicting reports are found in the literature regarding the impact of $\mathrm{P}$ fertilization on VAM. Some suggest that P fertilization reduces the rate of VAM infection (Clapperton et al., 1997) while others have found no difference in root infection with P fertilizer application (Jasper et al., 1979). In the FICS, starter fertilizer (10-34-0) was applied to wheat treatments at planting. If $\mathrm{P}$ had a negative affect on VAM infection, this may offer another explanation for lower concentrations of $\mathrm{C}_{16} 6_{\text {vam }}$ in wheat compared with other crop treatments. Additionally, 1999 wheat yields were above average, while corn and millet yields were reduced for lack of sufficient precipitation. Hetrick et al. (1984) found that drought-stress enhances VAM colonization in corn plants with low $\mathrm{P}$ fertilization. Therefore, it is also possible that mycorrhizal populations were heightened in response to corn and millet water requirements.

Lastly, FAME analysis recovers alkaline-hydrolyzable fatty acids from hyphal membranes, spores and storage products. Neutral lipids, which contain $\mathrm{C}_{16} 6_{\text {vam }}$, can occur in higher concentrations in spores (Olsson and Johansen, 2000) and, for some VAM species, sporulation is highly affected by host plant affinity (Hetrick and Bloom, 1986). Tillage is also believed to favor spore-forming VAM species (Kurle and Pfleger, 1996) and the FICS site was managed using conventional tillage prior to 1999. Thus, heightened concentrations of $\mathrm{C}_{16} 6_{\text {vam }}$ in the corn and millet treatments of the FICS may reflect enhanced VAM spore formation stemming from drought conditions. Further research is required to determine (i) the relationship between soil $\mathrm{C}_{16} 6_{\text {vam }}$ concentrations and VAM root infection intensity, and (ii) the factors underlying variations in $\mathrm{C} 16_{\text {vam }}$ concentration among cropping treatments.

Concentrations of the four glomalin fractions, total, EET, IRT, and IREE, were not different among crops, yet all were negatively related to $\mathrm{EC}_{\mathrm{a}}$ zones as: high $<$ medium high $<$ medium low $<$ low when evaluated across replicates and crop treatments (Table 2). Figure 3 illustrates trends toward IRT glomalin partitioning among $\mathrm{EC}_{\mathrm{a}}$ zones within crop treatments, an indication of the strength of the relationship between IRT glomalin and $\mathrm{EC}_{\mathrm{a}}$. Only $\mathrm{EE}$ and IREE glomalin, fractions believed to be most recently deposited, showed significant crop* $\mathrm{EC}_{\mathrm{a}}$ interactions ( $P=0.023$ and $P=0.098$, respectively). Thus, glomalin appears to be a static or historical indicator of VAM activity, where measured levels at the FICS largely reflect VAM response to the wheat-fallow conventional-tillage management practiced prior to 1999. The recalcitrant nature of glomalin and its accumulation in soil have been corroborated by other researchers (Rillig et al., 2001). Total glomalin 


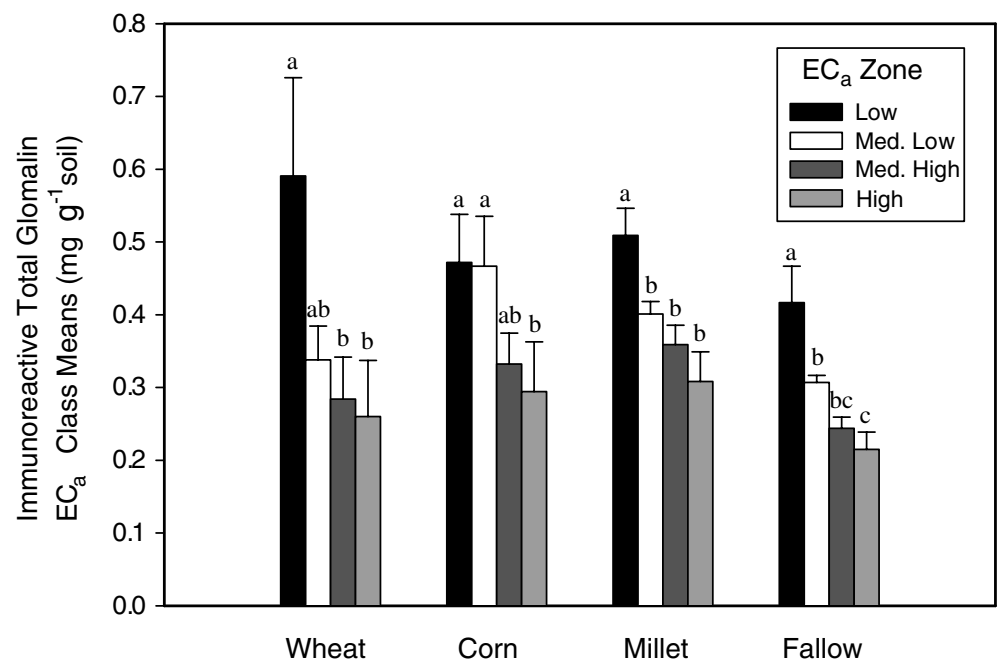

Figure 3. The $\mathrm{EC}_{\mathrm{a}}$ class means of immunoreactive total glomalin within cropping treatments. Error bars represent the standard errors of the mean $(n=6)$. Bars associated with the same letter, within crop treatments, were not significantly different among $\mathrm{EC}_{\mathrm{a}}$ classes (0.05).

analyses for ${ }^{14} \mathrm{C}$ estimate a soil residence time of 6-42 years (personal communication, Sara Wright).

Total glomalin was correlated with WAS, although there was no relationship between other glomalin fractions and WAS. This is similar to findings by Franzluebbers et al. (2000) but contrary to those of Wright and Upadhyaya (1998) who found easily extractable and immunoreactive glomalin fractions to be more strongly correlated with WAS than total glomalin. This discrepancy may be a consequence of scale, multiple geographic locations examined by Wright and Upadhyaya versus localized spatial heterogeneity at the FICS site. Assuming that EE and IR fractions represent recent glomalin production, it is also possible that comparatively low glomalin deposition rates in semiarid systems, such as the FICS, may preclude association with WAS. Lastly, the passage of soil samples through a 2-mm sieve at the time of collection may have altered the aggregate characteristics of soils from the FICS, thereby masking the strength of relationships between WAS, $\mathrm{EC}_{\mathrm{a}}$, and glomalin fractions.

\section{Wheat yield analyses (field-scale)}

Comparisons between $\mathrm{EC}_{\mathrm{a}}$ and 2 years of winter wheat yield maps corroborate sampling-site scale findings indicating a negative relationship between $\mathrm{EC}_{\mathrm{a}}$ and yield potential. Strong negative correlations were found between $\mathrm{EC}_{\mathrm{a}}$ and wheat yields, particularly when mean wheat yields within $\mathrm{EC}_{\mathrm{a}}$-classified zones were regressed against mean $\mathrm{EC}_{\mathrm{a}}$ within $\mathrm{EC}_{\mathrm{a}}$ zones (Figure 4). Field 8 has significantly higher yields in the low $\mathrm{EC}_{\mathrm{a}}$ zones and greater yield separation among zones (steeper slope) 


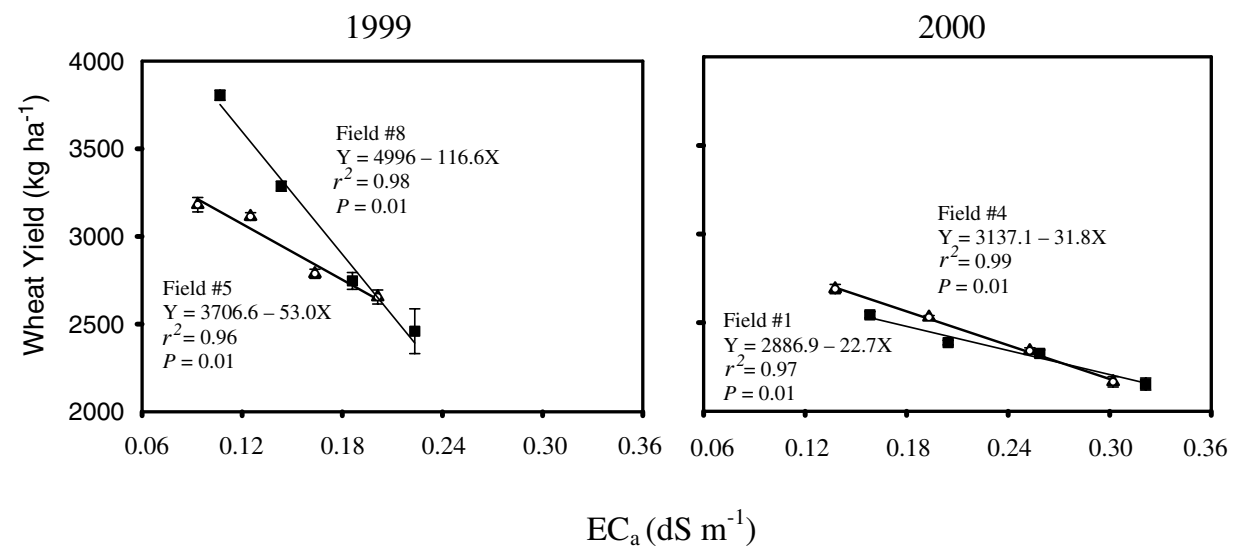

Figure 4. Mean wheat yield, within $\mathrm{EC}_{\mathrm{a}}$ zones, for 1999 and 2000 regressed against mean $\mathrm{EC}_{\mathrm{a}}$, within $\mathrm{EC}_{\mathrm{a}}$ class. The error bars represent the standard error of the mean.

compared to fields 1, 4 and 5. This is likely attributable to its position at the southern end of the south-sloping FICS site. Down-slope soils are typically deeper and higher in organic matter than those at higher elevations resulting in heightened production potential. Comparison of mean across-field and within $\mathrm{EC}_{\mathrm{a}}$-zone organic matter revealed that the highest levels were in field 8 . In addition, run-off provides field 8 with greater precipitation inputs than are received by the other fields evaluated. Johnson et al. (2003) provides additional information regarding $\mathrm{EC}_{\mathrm{a}}$-yield relationships at the FICS site.

\section{Relating measurements within a hierarchy of scale}

Because the FICS site is characterized by calcareous soils, the erosion of topsoil exposes underlying horizons and raises surface-soil clay content, $\mathrm{CaCO}_{3}$, and bulk density, all factors increasing measured $\mathrm{EC}_{\mathrm{a}}$. For this reason, soil physical and chemical properties related to erosion phase (bulk density, percent clay, laboratorymeasured $\mathrm{EC}_{\mathrm{a}}$, and $\mathrm{pH}$ ) were positively correlated with $\mathrm{EC}_{\mathrm{a}}$ (Johnson et al., 2001). Conversely, soils found in non- or less-eroded parts of each field had lower levels of clay and $\mathrm{CaCO}_{3}$, and lower bulk densities, resulting in lower measured $\mathrm{EC}_{\mathrm{a}}$. Since low $\mathrm{EC}_{\mathrm{a}}$ regions were also higher in factors related to production potential, notably soil organic matter, total $\mathrm{C}$ and $\mathrm{N}$, extractable $\mathrm{P}$, microbial biomass $\mathrm{C}$ and $\mathrm{N}$, and moisture content, they were positively correlated with winter wheat yields (Johnson et al., 2003) and negatively correlated with $\mathrm{EC}_{\mathrm{a}}$.

Classification by $\mathrm{EC}_{\mathrm{a}}$ can be used to integrate these findings with soil biological assessments also linked to $\mathrm{EC}_{\mathrm{a}}$. For instance, a relationship can be documented between IRT glomalin, produced at the micron level, and winter wheat yields, assessed at the field scale (Figure 5). While other researchers have produced indirect evidence of this association, wherein IRT glomalin contributes to soil C concen- 


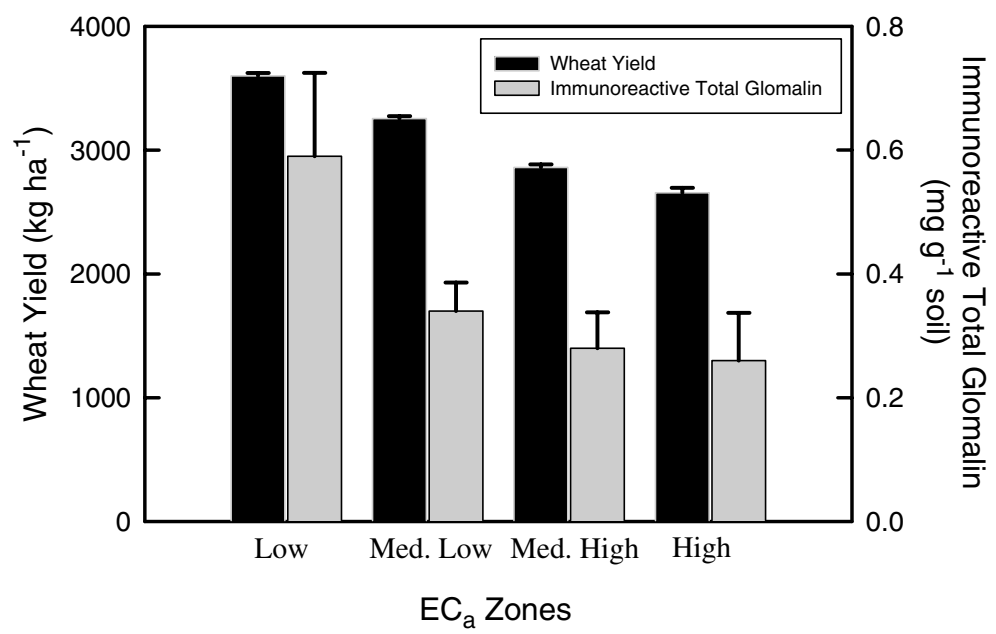

Figure 5. Relationship between the within-EC $\mathrm{E}_{\mathrm{a}}$ class means of 1999 wheat yield data and immunoreactive (IR) total glomalin. A yield monitor was used to collect yield data from two replicate fields for subsequent interpolation using a $10-\mathrm{m}$ grid. Glomalin concentrations represent the mean of six samples collected within the two wheat fields. Error bars depict the standard error of the mean.

trations, and soil C is correlated with crop yield (Anderson, 1998; Rillig et al., 2001), $\mathrm{EC}_{\mathrm{a}}$-based classification allows direct linkage at large experimental scales.

Significant information regarding soil environmental selective pressures on VAM populations can also be gleaned by merging microbial and whole-soil physical and chemical data collected within the $\mathrm{EC}_{\mathrm{a}}$-zone framework. For example, total and IRT glomalin were strongly delineated among $\mathrm{EC}_{\mathrm{a}}$ zones and positively correlated with soil total $\mathrm{C}$, particulate organic matter, extractable $\mathrm{P}$, and water content (Table 3). These same correlations exist for EE and IREE glomalin fractions (data not shown). Such connections distinguish glomalin fractions as excellent indicators of within-field variations in soil condition, defined as the combined characteristics of a given soil that define its level of function as a medium for crop production and a contributor to air and water quality (Johnson et al., 2001).

All total and immunoreactive fractions of glomalin were negatively correlated with $\mathrm{EC}_{\mathrm{a}}$ (Tables 2 and 3), reinforcing previous findings that glomalin concentrations reflect soil benefits accrued with VAM activity (Wright and Millner, 1994). These $\mathrm{EC}_{\mathrm{a}^{-}}$ delineated associations appear to be more than just statistical, likely reflecting a mechanistic relationship between VAM fungal activity and soil characteristics driving measured $\mathrm{EC}_{\mathrm{a}}$ (and other soil characteristics with which they may be correlated). Yet, the negative relationship between glomalin and $\mathrm{EC}_{\mathrm{a}}$ probably indicates more than simply heightened VAM activity with improved soil condition. This is because soil physical and chemical properties influence organic matter turnover and protection (van Veen and Paul, 1981) and low $\mathrm{EC}_{\mathrm{a}}$ zones likely embody those soil characteristics conducive to the maintenance of organic materials, including glomalin.

Statistical comparison of microbial-scale analyses within the 1-2 $\mathrm{mm}$ aggregates $(0-7.5 \mathrm{~cm}$ depth) and sampling-site-scale indicators of soil condition $(0-7.5 \mathrm{~cm}$ 


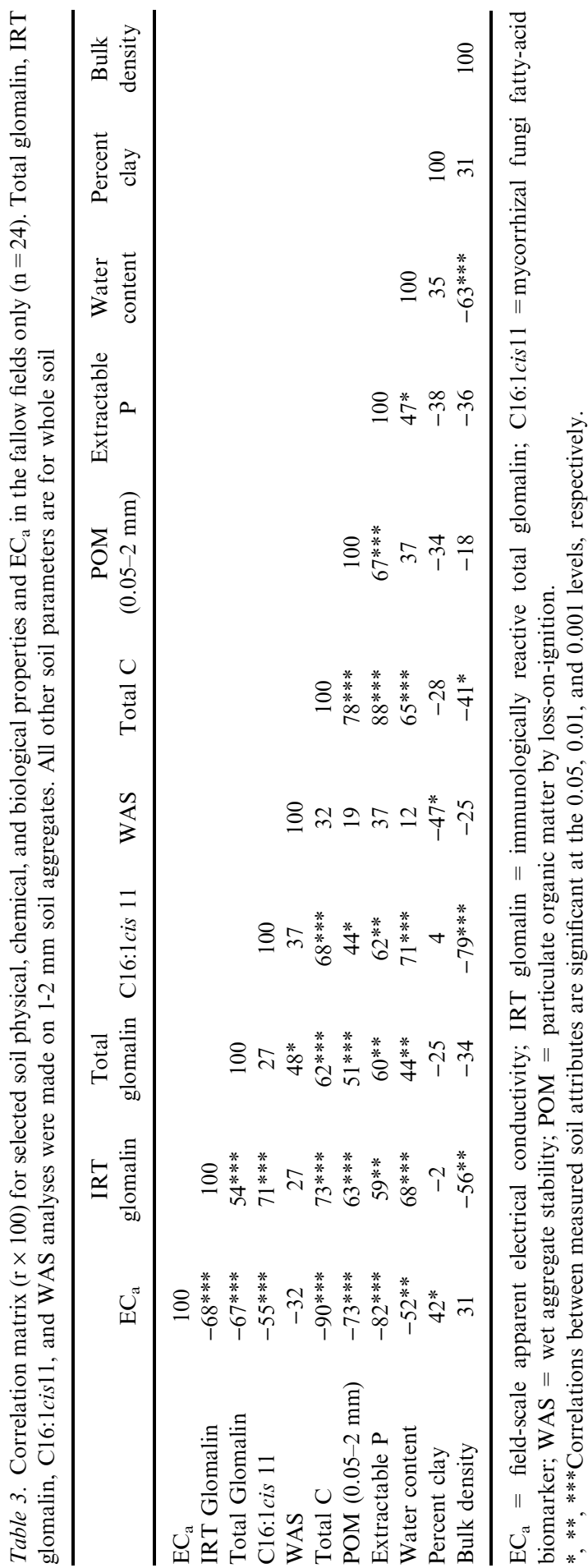


depth) were most significant in fallow treatments. Positive correlations were found between whole soil properties related to production potential and IRT glomalin, total glomalin, and $\mathrm{C} 16_{\text {vam }}$ (Table 3). Negative correlations were documented between measures of VAM and indicators of soil erosion, i.e. IRT glomalin or $\mathrm{C} 16_{\text {vam }}$ and bulk density, and WAS and clay content. Negative relationships have been previously reported between VAM propagule numbers and erosion (Day et al., 1987; Powell, 1980). Bethlenfalvay et al. (1985) showed that heterogeneity in soil condition affects the distribution of VAM fungi. Similarly, we found that WAS, glomalin, and C16 $6_{\text {vam }}$ concentrations were greatest in low- $\mathrm{EC}_{\mathrm{a}}$ zones, those parts of a field highest in organic matter. Increased levels of organic matter may accentuate hyphal length (St. John et al., 1983) and VAM inoculum viability (Hayman, 1982), both of which may have contributed to measured glomalin, C16 vam, and WAS at the FICS site.

\section{Conclusions}

The negative associations between $\mathrm{EC}_{\mathrm{a}}$ and microbial biomass $\mathrm{C}$ and $\mathrm{N}$ in whole soil, and between $\mathrm{EC}_{\mathrm{a}}$ and glomalin, $\mathrm{C} 16_{\text {vam }}$, and WAS in 1-2 mm soil aggregates, support the biological relevance of $\mathrm{EC}_{\mathrm{a}}$ classification. Glomalin, $\mathrm{C}_{1} 6_{\mathrm{vam}}$, and WAS proved to be sensitive measures of VAM presence and activity in soil, albeit for different aspects of organism function. Associations exist between soil (1) glomalin concentrations and $\mathrm{EC}_{\mathrm{a}}$ across crops and replicates, (2) WAS and $\mathrm{C}_{1} 6_{\text {vam }}$, and crop treatments, and (3) WAS and $\mathrm{Cl}_{\text {vam }}$, and $\mathrm{EC}_{\mathrm{a}}$ within fallow treatments (confounding effect of crop removed). These findings indicate that glomalin concentration is a static indicator of historical VAM activity that benefits the soil resource. We found all glomalin fractions to be excellent indicators of soil condition (production potential). The same can be said for WAS and $\mathrm{C} 16_{\text {vam }}$ when analyzed within fallow treatments to remove the confounding effect of crop. Additionally, WAS and $\mathrm{C}_{16} 6_{\text {vam }}$ were significantly differentiated among crops, implicating them as dynamic measures of VAM associations with a crop.

Glomalin, WAS, and $\mathrm{C}^{16} 6_{\text {vam }}$, biological indicators of VAM presence and activity, can be related to specific soil physical and chemical characteristics and crop yields due to significant partitioning of each of these parameters among $\mathrm{EC}_{\mathrm{a}}$ zones. Thus, $\mathrm{EC}_{\mathrm{a}}$ classification provides a point of reference through which microbial-, withinfield-, and field-scale data can be related. This $\mathrm{EC}_{\mathrm{a}}$ framework, when applied to the temporal appraisal of soil, crop, and farm economic parameters, may serve (1) as a basis for linking microbial-scale findings to farm-scale ecological and economic outcomes, and (2) for monitoring management-induced trends in agroecosystem function at the field scale. Additional research is necessary to determine the geographic extent to which these findings apply.

The ability to integrate data collected at multiple levels of scale may advance our understanding of management as a tool for manipulating VAM and other microbial populations to improve system productivity and sustainability. It also makes possible the study of management-crop-soil-microbe interactions within a spatial context, such that the continuum of intrinsic soil heterogeneity found within an agroecosystem can be addressed. 


\section{Notes}

1. Mention of a trademark, proprietary product or vendor does not constitute a guarantee of or warranty of the product by USDA nor imply its approval to the exclusion of other products that may be suitable.

\section{Acknowledgments}

We thank Russ and Matt Johnson, landowners and managers of the experimental site; Harold Duke, Gerald Buchleiter and Hamid Farahani for the Veris electrical conductivity mapping; and Kristine Nichols, Linda Jawson, Liz Jeske, Lisa Cooper, Aaron Schepers, Michael Schlemmer, Jane Clegg, Timothy Kettler, and Maribeth Milner for excellent technical assistance.

\section{References}

Allen, M. F., Clouse, S. D., Weinbaum, B. S., Jeakins, S. L., Friese, C. F. and Allen, E. B. 1992. Mycorrhizal Functioning (Chapman and Hall, New York), p. 489.

Anderson, R. L. 1998. Designing rotations for a semiarid region. In: Proceedings, 19th Annual Meeting, Colorado Conservation Tillage Association, pp. 12-24.

Bethlenfalvay, G. J., Ulrich, J. M. and Brown, M. S. 1985. Plant response to mycorrhizal fungi: Host, endophyte and soil effects. Soil Science Society of America Journal 49, 1164-1168.

Bowman, R. A. and Halvorson, A. D. 1997. Crop rotation and tillage effects on phosphorus distribution in the central Great Plains. Soil Science Society of America Journal 61, 1418-1422.

Bowman, R. A., Vigil, M. F., Nielsen, D. C. and Anderson, R. L. 1999. Soil organic matter changes in intensively cropped dryland systems. Soil Science Society of America Journal 63, 186-191.

Bray, R. H. and Kurtz, L. T. 1945. Determination of total, organic, and available forms of phosphorus in soils. Soil Science 59, 39-45.

Cambardella, C. A., Gajda, A. M., Doran, J. W., Wienhold, B. J. and Kettler, T. A. 2001. Estimation of particulate and total organic matter by weight loss on ignition. In: Assessment Methods for Soil Carbon, edited by R. Lal, J. M. Kimble, R. F. Follett and B. A. Steward (CRC Press, Boca Raton, FL), pp. 349-359.

Cavigelli, M. A., Robertson, G. P. and Klug, M. J. 1995. Fatty acid methyl ester (FAME) profiles as measures of soil microbial community structure. In: The Significance and Regulation of Soil Biodiversity, edited by H.P. Collins, G.P. Robertson and M. J. Klug (Kluwer Academic Publishers, The Netherlands), pp. 99-113.

Clapperton, M. J., Janzen, H. H. and Johnston, A. M. 1997. Suppression of VAM fungi and micronutrient uptake by low-level $\mathrm{P}$ fertilization in long-term wheat rotations. American Journal of Alternative Agriculture 12, 59-63.

Corwin, D. L., Lesch, S. M., Shouse, P. J., Soppe, R. and Ayars, J. E. 2003. Identifying soil properties that influence cotton yield using soil sampling directed by apparent soil electrical conductivity. Agronomy Journal 95, 352-364.

Day, L. D., Sylvia, D. M. and Collins, M.E. 1987. Interactions among vesicular-arbuscular mycorrhizae, soil, and landscape position. Soil Science Society of America Journal 51, 635-639.

Doran, J. W. 1980. Microbial changes associated with residue management with reduced tillage. Soil Science Society of America Journal 44, 518-524.

Doran, J. W. 1987. Microbial biomass and mineralizable nitrogen distributions in no tillage and plowed soils. Biology and Fertility of Soils 5, 68-75. 
Doran, J. W., Elliot, E. T. and Paustian, K. 1998. Soil microbial activity, nitrogen cycling, and long-term changes in organic carbon pools as related to fallow tillage management. Soil and Tillage Research 49 , $3-18$.

Doran, J. W. and Linn, D. M. 1994. Microbial ecology of conservation management systems. In: Advances in Soil Science - Soil Biology: Effects on Soil Quality, edited by J. L. Hatfield and B. A. Stewart, CRC Press, Boca Raton, FL), pp. 1-27.

Drijber, R. A., Doran, J. W., Parkhurst, A. M. and Lyon, D. J. 2000. Changes in soil microbial community structure with tillage under long-term wheat-fallow management. Soil Biology and Biochemistry 32, 1419-1430.

Eigenberg, R. A., Doran, J. W., Nienaber, J. A., Ferguson, R. B. and Woodbury, B. L. 2002. Electrical conductivity monitoring of soil condition and available $\mathrm{N}$ with animal manure and a cover crop. Agriculture, Ecosystems, and Environment 88, 183-193.

Ellis, J. R., Larsen, H. J. and Boosalis, M. G. 1985. Drought resistance of wheat plants inoculated with vesicular-arbuscular mycorrhizae. Plant and Soil 86, 369-378.

ERDAS, Inc. 1997. ERDAS Field Guide (ERDAS Inc., Atlanta, GA.), pp. 225-232.

Franzluebbers, A. J., Wright, S. F. and Stuedemann, J. A. 2000. Soil aggregation and glomalin under pastures in the southern piedmont USA. Soil Science Society of America Journal 64, 1018-1026.

Grogan, D. W. and Cronan J.E. Jr., 1997. Cyclopropane ring formation in membrane lipids of bacteria. Microbiology and Molecular Biology Reviews 61, 429-441.

Hayman, D. S. 1982. Influence of soils and fertility on activity and survival of vesicular-arbuscular mycorrhizal fungi. Phytopathology 72, 1119-1125.

Hendrix, P. F., Crossley, D. A., Blair, J. M. and Coleman, D. C. 1990. Soil biota as components of sustainable agroecosystems. In: Sustainable Agricultural Systems, edited by C. A. Edwards, R. Lal, P. Madden, R. H. Miller and G. House (Soil and Water Conservation Society, Ankeny, IA.), pp. 637654.

Hetrick, B. A. D. and Bloom, J. 1983. Vesicular-arbuscular mycorrhizal fungi associated with native tallgrass prairie and cultivated winter wheat. Canadian Journal of Botany 61, 2140-2146.

Hetrick, B. A. D. and Bloom, J. 1986. The influence of host plant on production and colonization ability of vesicular-arbuscular mycorrhizal spores. Mycologia 78, 32-36.

Hetrick, B. A. D., Hetrick, J. A. and Bloom, J. 1984. Interaction of mycorrhizal infection, phosphorus level and moisture stress in growth of field corn. Canadian Journal of Botany 62, 2267-2271.

Islam, K. R., Weil, R. R. and Mulchi, C. L. 1998. Microwave irradiation of soil for routine measurement of microbial biomass carbon. Biology and Fertility of Soil 27, 408-416.

Jasper, D. A., Robson, A. D. and Abbott, L. K. 1979. Phosphorus and the formation of vesiculararbuscular mycorrhiza. Soil Biology and Biochemistry 11, 501-505.

Johnson, C. K., Doran, J. W., Duke, H. R., Wienhold, B. J., Eskridge, K. M. and Shanahan, J. F. 2001. Field-scale electrical conductivity mapping for delineating soil condition. Soil Science Society of America Journal 65, 1829-1837.

Johnson, C. K., Mortensen, D. A., Wienhold, B. J., Shanahan, J. F. and Doran, J. W. 2003. Soil electrical conductivity mapping as a basis for site-specific management. Agronomy Journal 95, 303-315.

Johnson, N. C., Tilman, D. and Wedin, D. 1992. Plant and soil controls on mycorrhizal fungal communities. Ecology 73, 2034-2042.

Juma, N. G. 1993. Interrelationships between soil structure/texture, soil biota/soil organic matter and crop production. In: Soil Structure/Soil Biota Interrelationships, edited by L. Brussaard and M. J. Kooistra (Elsevier Science, Amsterdam, The Netherlands), pp. 3-30.

Kates, M. 1986. Techniques of lipidology: Isolation, analysis and identification of lipids. In: Laboratory Techniques in Biochemistry and Molecular Biology, Vol. 3, Part 2, edited by R. H. Burdon and P. H. van Kippenberg (Elsevier, NY, USA).

Kemper, W. D., Rosenau, R. C. 1986. Aggregate stability and size distribution. In: Methods of soil analysis, Part 1. Physical and mineralogical methods, Agronomy Monograph No. 9, 2nd ed., (American Society of Agronomy, Madison, WI, USA) pp. 425-444.

Kettler, T. A., Doran, J. W. and Gilbert, T. L. 2001. A simplified method for soil particle size determination to accompany soil quality analyses. Soil Science Society of America Journal 65, 849-852. 
Kettler, T. A., Lyon, D. J., Doran, J. W., Powers, W. L. and Stroup, W. W. 2000. Soil quality assessment after weed-control tillage in a no-till wheat-fallow cropping system. Soil Science Society of America Journal 64, 339-346.

Khakural, B. R. and Robert, P. C. 1998. Use of non-contacting electromagnetic inductive methods for estimating soil moisture across a landscape. Communications in Soil Science and Plant Analysis 29, 2055-2065.

Kurle, J. E. and Pfleger, F. L. 1996. The effects of cultural practices and pesticides on VAM fungi. In: Mycorrhizae and Plant Health, edited by F. L. Pfleger and R. G. Linderman (APS Press, St. Paul, Minnesota), pp. 101-131.

Lesch, S. M., Rhoades, J. D., Lund, L. J. and Corwin, D. L. 1992. Mapping soil salinity using calibrated electromagnetic measurements. Soil Science Society of America Journal 56, 540-548.

McNeill, J. D. 1980. Electrical conductivity of soils and rocks. Technical Note TN-5. (Geonics Limited, Mississauga, Ontario, Canada).

Miller, R. M. and Jastrow, J. D. 1992. The role of mycorrhizal fungi in soil conservation. In: Mycorrhizae in Sustainable Agriculture (American Society of Agronomy, Special Publication no. 54).

Olsson, P. A. and Johansen, A. 2000. Lipid and fatty acid composition of hyphae and spores of arbuscular mycorrhizal fungi at different growth stages. Mycology Research 104, 429-434.

Olsson, P. A., Bååth, E., Jakobsen, I. and Söderström, B. 1995. The use of phospholipid and neutral lipid fatty acids to estimate biomass of arbuscular mycorrhizal fungi in soil. Mycological Research 99, 623629.

O’Neill, E. G., O’Neill, R. V., and Norby R. J. 1991. Hierarch theory as a guide to mycorrhizal research on large-scale problems. Environmental Pollution 73, 2721-2784.

Powell, C. L. 1980. Mycorrhizal infectivity of eroded soils. Soil Biology and Biochemistry 12, 247-250.

Rhoades, J. D., Manteghi, N. A., Shouse, P. J. and Alves, W.J. 1989. Soil electrical conductivity and soil salinity: New formulations and calibrations. Soil Science Society of America Journal 53, 433-439.

Rillig, M. C., Wright, S. F., Nichols, K. A., Schmidt, W. F. and Torn, M. S. 2001. Large contribution of arbuscular mycorrhizal fungi to soil carbon pools in tropical forest soils. Plant and Soil 233, 167-177.

SAS Institute 1997. SAS/STAT Software: Changes and enhancements through release 6.12. (SAS Inst., Carey, NC, USA).

St. John, T. V., Coleman, D. C. and Reid, C. P. P. 1983. Association of vesicular arbuscular mycorrhizal hyphae with soil organic particles. Ecology 64, 957-959.

Sylvia, D. M., Fuhrmann, J. J., Hartel, P. G. and Zuberer, D. A. 1998. Principles and Applications of Soil Microbiology (Prentice-Hall, Inc., Upper Saddle River, New Jersey, USA), pp. 402-403.

Tisdale, J. M. and Oades, J. M. 1982. Organic matter and water-stable aggregates in soils. Journal of Soil Science 33, 141-163.

van Veen, J. A. and Paul, E. A. 1981. Organic carbon dynamics in grassland soils. I. Background information and computer simulation. Canadian Journal of Soil Science 61, 185-201.

White, D. C., Davis, W. M., Nickels, J. S., King, J. D. and Bobbie, R. J. 1979. Determination of the sedimentary microbial biomass by extractable lipid phosphate. Oecologia 40, 51-62.

Williams, B.G. and Hoey, D. 1987. The use of electromagnetic induction to detect the spatial variability of the salt and clay contents of soils. Australian Journal of Soil Research 25, 21-27.

Wright, S. F. and Anderson, R. L. 2000. Aggregate stability and glomalin in alternative crop rotations for the central Great Plains. Biology and Fertility of Soils 31, 249-253.

Wright, S. F. and Millner, P. D. 1994. Dynamic processes of vesicular-arbuscular mycorrhizae: A mycorrhizosystem within the agroecosystem. In: Soil Biology: Effects on Soil Quality, edited by J. L. Hatfield and B. A. Stewart (Lewis Publishers, Boca Raton, FL, USA), pp. 29-59.

Wright, S. F. and Upadhyaya, A. 1996. Extraction of an abundant and unusual protein from soil and comparison with hyphal protein of arbuscular mycorrhizal fungi. Soil Science 161, 565-586.

Wright, S. F. and Upadhyaya, A. 1998. A survey of soils for aggregate stability and glomalin, a glycoprotein produced by hyphae of arbuscular mycorrhizal fungi. Plant and Soil 198, 97-107.

Yocum, D. H., Larsen, H. J. and Boosalis, M. G. 1985. The effects of tillage treatments and a fallow season on VA mycorrhizae of winter wheat. In: Proceedings of 6th North American Conference on Mycorrhizae, Bend Oregon. (Forest Research Laboratory, Corvallis, OR, USA), pp. 297. 